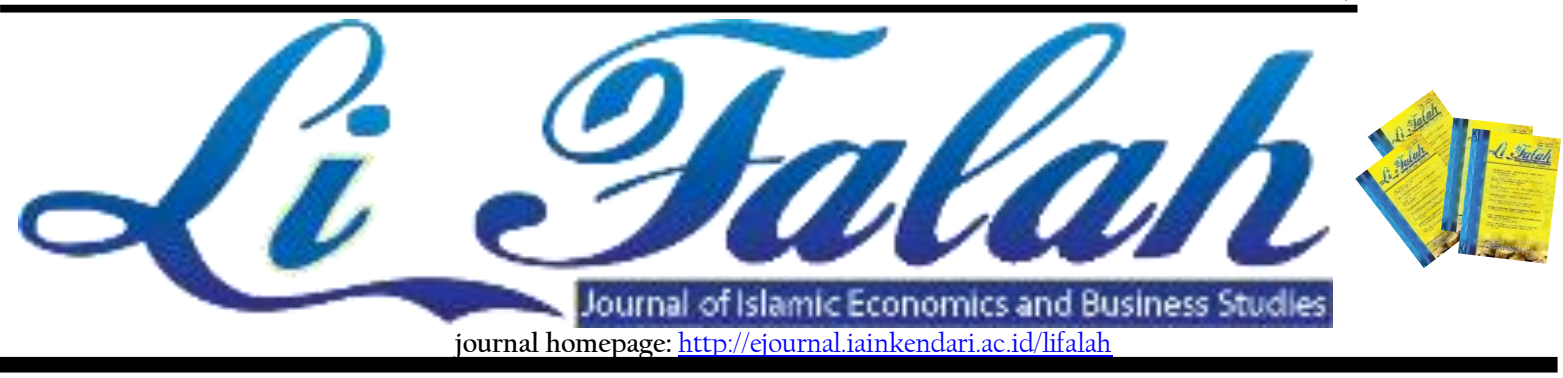

\title{
Measurement of the Zakat Transparency Index of Amil Zakat Institutions (LAZ) in Banten Province, Indonesia.
}

\section{Ahmad Fatoni ${ }^{1}$ dan Muhamad Fakhrudin ${ }^{2}$}

1,2Universitas Sultan Ageng Tirtayasa

Emai:ahmadfatoni@untirta.ac.id, syalymaula@gmail.com

\begin{tabular}{|c|c|}
\hline ARTICLE INFO & A B S T R A C T \\
\hline Article History: & As an institution that manages social funds, transparency \\
\hline Received April ll, 2021 & must be met for the Amil Zakat Institution. By measuring \\
\hline April 2021 & the zakat transparency index, the Amil Zakat Institution \\
\hline $2^{\text {st }}$ Received in revised form 24 Mei & can determine the extent of implementing transparency in \\
\hline 2021 & the organization. Information disclosure to the public \\
\hline Available online 30 Juni 2021 & increases public confidence in paying zakat at the Amil \\
\hline & $\begin{array}{l}\text { Zakat Institution. This study aims to measure the zakat } \\
\text { transparency index of the Amil Zakat Institution in }\end{array}$ \\
\hline Keywords: & Banten Province. The Simple Additive Weighting (SAW) \\
\hline credit, non-performing loan, corporate & method is used to calculate the transparency index of \\
\hline & zakat institutions. The Simple Additive Weighting (SAW) \\
\hline \multirow{6}{*}{$\begin{array}{l}\text { http://dx.doi.org/10.31332/lifalah } \\
\text {.v6i1.2262 }\end{array}$} & method is a multiple attribute retrieval method, where the \\
\hline & weight of each predetermined dimension is multiplied by \\
\hline & each variable weight, then added up. The results showed \\
\hline & that the Amil Zakat Institution in Banten Province was \\
\hline & included in the reasonably transparent category with an \\
\hline & index of 0.706. \\
\hline
\end{tabular}

\section{Introduction}

Poverty and economic inequality are still common problems faced by Banten Province. The Central Statistics Agency (2019) noted that in semester 1 of 2019, the poverty rate in Banten province reached 5.09 percent. This figure is 0.15 percent lower than the poverty rate in 2018 in the same semester. In addition, Banten Province is also still facing economic disparities. The Central Statistics Agency (2019) reported that the Gini ratio in semester 1 reached 0.365 from 1, which was lower than 2018 in the same semester of 0.020. Therefore, even though the poverty rate and inequality in Banten 
Province are decreasing from year to year, these problems still exist and become a joint work to be solved.

In Islam, zakat is one of the most relevant social-economic instruments in helping the government to reduce poverty and inequality. The results of an empirical study conducted by Puskas BAZNAS show that zakat has a significant impact on poverty, especially in Banten Province (Puskas Baznas, 2019a).

Tabel 1 The Impact of Zakat on Mustahik's Welfare Based on the Poverty Index in Banten Province in 2018

\begin{tabular}{|c|c|c|c|c|c|}
\hline & Headcount & Income Gap & Proverty Gap & Sen Index & FGT Index \\
\hline Before & 0,34 & 0,05 & 711951 & 0,16 & 0,09 \\
\hline After & 0,19 & 0,04 & 608668 & 0,09 & 0,04 \\
\hline$\Delta$ & 0,1496 & 0,01 & 103283 & 0,0691 & 0,0474 \\
\hline
\end{tabular}

Source: Puskas Baznas (2019a)

Based on table 1, the Banten Province Headcount index value decreased after receiving zakat funds. This data indicates a decrease in the number of the poor, in this case, mustahik, due to the assistance of zakat funds. For example, the value of $\mathrm{H}$ before the zakat fund assistance in Banten Province was 0.34, while after the intervention of zakat funds, the value of $\mathrm{H}$ became 0.19 or decreased by 14 percent. Meanwhile, the Income Gap value for Banten Province before receiving zakat assistance was 0.05. However, this value decreased to 0.04 after receiving zakat funds. This data shows that the income gap after receiving zakat funds is lower than before zakat funds and illustrates that the poor group's situation is getting better.

Furthermore, the value of $\mathrm{P} 1, \mathrm{P} 2, \mathrm{P} 3$ also decreased after receiving zakat funds. This data shows that the poverty gap is getting smaller or reduced by Rp.103,283. Likewise, the value of poverty severity (Sen Index and FGT Index) shows a decreasing value. Indonesia has an enormous zakat potential as a country with the largest Muslim population globally. Several empirical studies state that the potential value of Indonesian zakat is above Rp. 200 trillion, as suggested by Firdaus et al. (2012) and Asfarina et al. (2018).

Meanwhile, in 2019, the BAZNAS Puskas conducted a Zakat Mapping Potential Indicators (IPPZ). The results of the IPPZ study show that the potential for zakat in Indonesia in 2019 reaches Rp.233.8 trillion. However, the various studies above describe the potential for zakat in Indonesia. It has not been supported by achievements in collecting zakat in the field. This data means that there is a very high gap between the potential and reality of the collection. Judging from the statistical report of Baznas (2018), the actual data on the collection of national Zakat, Infaq, and Alms (ZIS) by the official 
Zakat Management Organization (OPZ), in 2018, the group of ZIS only reached around Rp. 8 trillion, it means that the realization of the collection is still far from its potential. This condition reflects the provinces in Indonesia, including Banten Province, where the ZIS potential in 2017 is around Rp. 7 trillion (Zakat Potential Mapping Indicator, 2019); however, the realization of the collection is only around Rp. Sixteen billion (Indonesia Zakat Outlook, 2018).

According to Huda and Sawarjuwono (2013), the large number of muzakki who pay zakat directly to mustahik without intermediary zakat institutions is one of the leading causes of the imbalance between the potential of zakat funds and their realization. This data illustrates that still, people do not believe in the Zakat Management Organization (OPZ). Ascarya and Yumanita (2019), in their research, found that the low level of transparency of the Zakat Management Organization (OPZ) was the leading cause of the typical collection of zakat funds. Transparency is an essential dimension in measuring the credibility of an institution's financial management accountability. Transparency is one of the principles in Good Corporate Governance (GCG). There are at least four GCG principles: transparency, accountability, responsibility, equality, and fairness. For a zakat institution, the trust of muzakki in paying their zakat obligations is formed from their perceptions regarding the management of zakat funds. The level of confidence of the muzakki is related to the reputation of the Zakat Management Organization (OPZ), accountability for information disclosure, the effectiveness of zakat management, and the satisfaction of muzaki with zakat payment services (Nurfadhilah and Sasongko, 2019). Thus, the level of transparency of financial and non-financial information is the key to the trust of every stakeholder. So it is necessary to measure the level of transparency of Zakat Management Organizations (OPZ), especially in Banten Province. Knowing the Zakat Management Organization (OPZ) level of transparency will always make a positive contribution to increasing transparency to realize public trust. 


\section{Literature Review}

\subsection{Transparency Theory}

Transparency provides open and honest financial information to the public based on the consideration that the public has the right to know openly and thoroughly the responsibility for managing the resources entrusted to them. According to Hasan (2011), transparency is openness in implementing the decision-making process and presenting relevant material and information about the company. Sending reports to all parties openly related to management operations by including all elements as the basis for decision-making and implementing activities. Disclosure of information determines the reliability of a financial statement. Williams (2005) revealed that transparency has three elements, namely relevance, timeliness, and reliability.

Meanwhile, Dubbink et al. (2007) define transparency as having effectiveness, freedom, virtue, and trust in the organization. In his research, transparency is often described as conscientious communication, impartiality, and far from manipulation. Thus, the primary purpose of transparency in communication and openness (Barth and Landsman, 2013).

Transparency is often described as conscientious communication instead of partiality and manipulation (Bushman et al., 2004). The subject of transparency depends on information, including financial and non-financial information, economic and social responsibility disclosures, annual reports, internet sites, communication channels, information dissemination, etc. Transparency determines accountability mechanisms. The transparency system helps improve the quality of financial reporting and accountability mechanisms.

\subsection{Transparency in Islamic Perspective}

Although it does not explicitly explain the implementation of transparency, the Qur'an does explain how one should behave to create transparency. Among the values related to this are transparency, accountability, and justice. Among these verses are QS. Al-Baqarah/2:282, Al-Isra '/17:35, and Al-Muthaffifin/83:1-5.

How is the picture of Islam regarding transparency, seen from the pattern and personality characteristics of the Prophet Muhammad, Antonio (2002) explains this:

a. Sidiq's primary value is integrity. Among the values in business can be seen from honesty, sincerity, assurance, and emotional balance. 
b. Tabligh's primary value is communicative. Among the values in the business world can be seen from the attitude of persistent salespeople, job descriptions, a delegation of authority, teamwork, coordination, control, and supervision.

c. The primary value of trust is trustworthiness; it is revealed that there is trust, responsibility, transparency, and time from the business.

Transparency is a condition of openness to all actions and policies of the authorities. The intended source is an institution authorized by the state to manage zakat funds in zakat management. The Zakat Management Organizations following Law No.23 of 2011 are the National Amil Zakat Agency (BAZNAS) and the Amil Zakat Institution (LAZ).

Transparency in zakat management requires openness in the collection, management, and distribution of zakat funds. In zakat finance, transparency can be understood as disclosing financial sources, amounts, details of use, and accountability in front of stakeholders. The concept of transparency affects the procedures for reporting Islamic financial accounting. There are two main criteria for disclosing Islamic accounting reporting: the perception of social accountability and the rules regarding disclosure. Responsibility in Islam can be in the form of accountability before Allah and responsibility before humans (Gambling and Karim, 1986; Haniffa, 2002; Lewis, 2006). Saad et al. (2014), in their research, provide a comprehensive explanation that is structured within the framework of Islamic accountability in zakat management

Figure 1 Islamic Accountability Framework in the Management of Zakat Funds

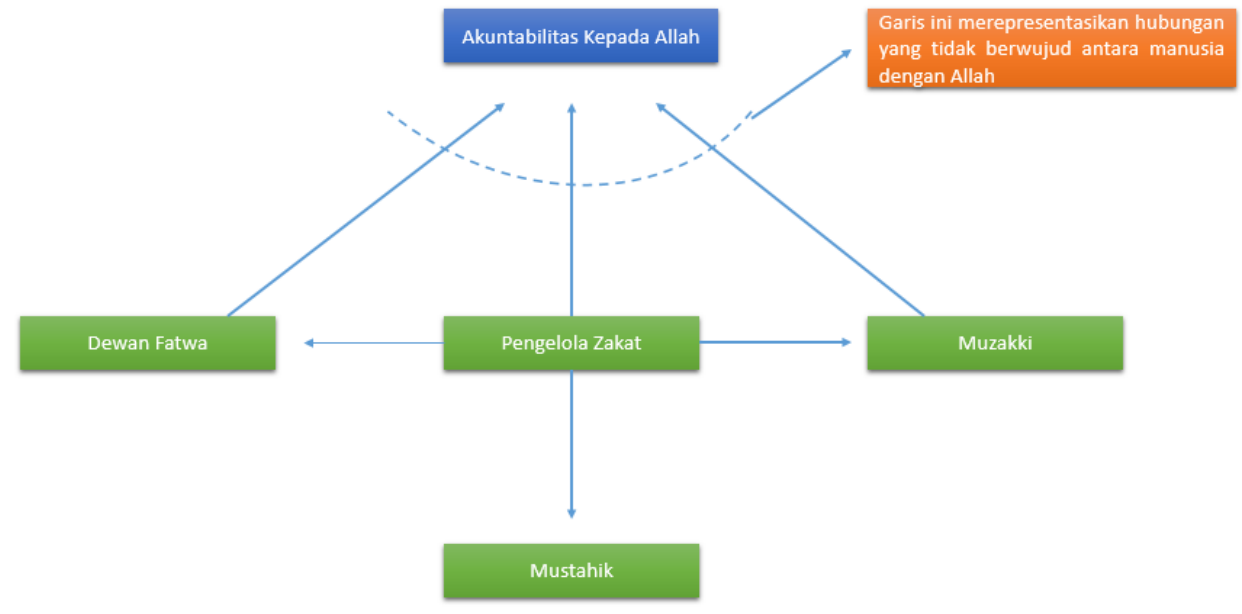

Source: Saad et al. 1. (2014) 
Figure 1. Explains that zakat managers directly manage zakat funds to muzakki, mustahik, and the fatwa council regarding Islamic sharia compliance. Everyone has their responsibility to Allah SWT. Meanwhile, accountability and transparency for zakat management organizations refer to Zakat Core Principles No. 17 concerning Disclosure and Transparency requiring the publication of reporting information that is easy to access by stakeholders.

\subsection{Zakat Transparency Measurement Model}

\subsubsection{State of The Art}

Several studies, both related to zakat and non-zakat, have measured the level of transparency. Bushman et al. (2004) measure transparency by using three elements: corporate reporting, personal information and communication, and information dissemination. Barth and Schipper (2008) state several approaches to measuring transparency, including market analysis, perception, and accounting analysis. Meanwhile, Williams (2015) developed a model that can measure transparency by using indicators of information disclosure on quantity, quality, and infrastructure. More specifically, Behn et al. (2010) conducted an exploration that investigated the determinants of transparency in nonprofit organizations. The factors included in the research include the ratio of total year-end liabilities, the percentage of contributions to total income, the proportion of total compensation of officers and directors to total revenue, attributes if an organization is classified as a university, log of total assets at the end of the year.

At the level of transparency of zakat, researchers also have different measuring tools. For example, Amalia et al. (2018) see zakat transparency as part of good governance. Indicators measure the level of transparency using secondary data such as the availability of a website to apply the principle of transparency and the availability of financial reports that inform their collection, distribution, and use. Likewise, Adnan et al. (2017) saw the transparency of zakat management institutions in Malaysia from the availability of periodic financial reports. Meanwhile, in their research, Nasri et al. (2019) found that transparency has a significant positive effect on the financial performance of zakat institutions. There are several indicators to measure transparency: providing written information or data to muzakki on time, providing data or information at the zakat office related to funding management, and disclosing information on policies/rules of zakat institutions in the direction of zakat funds.

Based on several previous studies where zakat transparency is only seen from published financial reports, this cannot describe the overall management of zakat funds. 
Moreover, measuring the openness of web-based zakat fund management can also allow fraud to occur. Therefore, we need an index that can measure the transparency of zakat management that can describe the overall zakat management activities, the dimensions of financial transparency, management transparency, and program transparency. In 2019 the National Amil Zakat Agency provided guidelines for measuring zakat transparency, called the Zakat Management Organization Transparency Index (OPZ) (Puskas Baznas, 2019). Therefore, researchers measuring the Amil Zakat Institution (LAZ) openness in Banten province use this Index.

\subsubsection{Transparency Index of Zakat Management Organizations (OPZ)}

Puskas Baznas (2019b) has initiated a method to measure the level of transparency in OPZ using the OPZ transparency index. There are three main dimensions to be measured in the Index, namely the dimensions of openness in the financial statements of OPZ, transparency of OPZ management, and clarity of OPZ programs. First, the transparency of financial statements is divided into two variables: the publication of financial statements and the quality of financial reports. Meanwhile, the second dimension is divided into four variables: Standard Operating Procedure (SOP), Company Profile, Data Information Center (PID), and complaint channel system. Then, the third dimension is divided into real-time activity variables of collection and distribution, the database of muzakki and mustahik, and the database of collection and distribution of zakat. By using the Simple Additive Weightage (SAW) approach, it is possible to measure the level of transparency of OPZ, which can be formulated as follows:

$$
\text { Total ITOPZ }=\sum_{i=1}^{n} W d i x D i
$$

Where:

Total ITOPZ : Transparency Index Value of Zakat Management Organizations

Wdi : Weighting value affixed to dimension $\mathrm{i}$

Di : Index value obtained on dimension i

After measuring the three dimensions, then categorizing the index calculation results with a value range of $0.00-1.00$, which means that if the index value is closer to 1.00, the better the level of transparency in an OPZ. 


\section{Research Method}

This study aims to measure the transparency index of zakat institutions. The authors refer to the OPZ transparency index issued by the Center for Strategic Studies (PUSKAS) of the National Amil Zakat Agency (BAZNAS) in calculating this transparency index.

This study of the zakat institution transparency index uses a quantitative approach. The Simple Additive Weighting (SAW) method is used to calculate the transparency index of zakat institutions. The Simple Additive Weighting (SAW) method is a multiple attribute retrieval method, where the weight of each predetermined dimension is multiplied by each variable weight, then added up.

The transparency index of Zakat Management Organizations (OPZ) in this study uses several dimensions, variables, and indicators components of the index preparation.

Table 2 Dimensions, Variables, and Indicators of OPZ Transparency Index

\begin{tabular}{|c|c|c|c|}
\hline No & Dimensions & Variables & Indicator \\
\hline \multirow{5}{*}{1} & \multirow{5}{*}{$\begin{array}{l}\text { Financial } \\
\text { Transparency } \\
\text { (Xl) }\end{array}$} & \multirow{2}{*}{$\begin{array}{l}\text { Publication of } \\
\text { Financial Statements } \\
(\mathrm{Xl} .1)\end{array}$} & Website Report \\
\hline & & & Mass Media Publications \\
\hline & & \multirow{3}{*}{$\begin{array}{l}\text { Financial statements } \\
(\mathrm{X} 1.2)\end{array}$} & $\begin{array}{l}\text { Use of Information Systems and } \\
\text { BAZNAS Management (SIMBA }\end{array}$ \\
\hline & & & Reporting Timeliness \\
\hline & & & Opini Auditor Independen \\
\hline \multirow{6}{*}{2} & \multirow{6}{*}{$\begin{array}{l}\text { Transparency } \\
\text { Management } \\
\text { (X2) }\end{array}$} & \multirow[t]{3}{*}{ Governance (X2.1) } & $\begin{array}{l}\text { There are Standard Operations } \\
\text { Procedures (SOPs) and ISO Standards }\end{array}$ \\
\hline & & & The Strategic Plan \\
\hline & & & Annual Budget Work Plan \\
\hline & & $\begin{array}{l}\text { Organisational } \\
\text { structure (X2.2) }\end{array}$ & $\begin{array}{l}\text { Organizational structure: Profile } \\
\text { management, member profile, system } \\
\text { staffing. }\end{array}$ \\
\hline & & $\begin{array}{l}\text { Information Portal and } \\
\text { Documentation (PID) } \\
\text { (X2.3) }\end{array}$ & $\begin{array}{l}\text { Availability of Information Portal and } \\
\text { Public Documentation (PID) }\end{array}$ \\
\hline & & $\begin{array}{l}\text { Complain, Chanel, } \\
\text { (X2.4) }\end{array}$ & There is a Complaint Channel System \\
\hline \multirow[t]{7}{*}{3} & \multirow{7}{*}{$\begin{array}{l}\text { Transparanci } \\
\text { Program (X3) }\end{array}$} & \multirow{2}{*}{$\begin{array}{l}\text { Aktivitas Real-time } \\
\text { (X3.1) }\end{array}$} & Collection Activity (Real-time) \\
\hline & & & Channeling Activities (Real-time) \\
\hline & & \multirow{3}{*}{$\begin{array}{l}\text { Database Muzaki and } \\
\text { Mustahik (X3.2) }\end{array}$} & Individu Muzaki Database \\
\hline & & & Agency Muzaki Database \\
\hline & & & Muzaki Database \\
\hline & & \multirow{2}{*}{$\begin{array}{l}\text { Program Data } \\
\text { Collection and } \\
\text { Distribution (X3.3) }\end{array}$} & Database Collection \\
\hline & & & Database Distribution \\
\hline
\end{tabular}

Source: Puskas Baznas (2019b) 


\subsection{Data Types and Sources}

The type of data used in this study is primary data sourced from structured interviews and the consequences of questionnaires at the zakat institutions studied when the transparency index was implemented. While the secondary data used is the zakat institutions' financial statements. Sources of data were obtained from the website and the results of the internal audit of zakat institutions.

\subsection{2. Population and Sample}

The population in this study is the Amil Zakat Institution (LAZ) on a national and provincial scale in Banten province. There are four LAZs on a national scale and one LAZ on a regional scale used as a population. The four national scale LAZs include LAZ Dompet Dhuafa Republika, LAZ Griya Yatim Dhuafa Foundation, LAZ Daarul Qur'an Nusantara (PPPA) Foundation and LAZ Baitul Ummah Banten Foundation. While the LAZ on the provincial scale is LAZ Harapan Dhuafa Banten.

The sampling technique in this study used saturated sampling. Saturated sampling is a sampling technique if all population members are sampled. This sample is used if the population is small, less than 30 . Therefore, the five people in this study were used as research samples.

\subsection{OPZ Transparency Index Calculation Model and Stages}

The model for calculating the transparency index of zakat managers from the Amil Zakat Institution (LAZ) in stages is as follows:

1. Make a Likert scale scoring with a range of $1-5$, where 1 describes the worst condition and 5 is the best condition. This score is made for all variables that make up the transparency index. Details of scoring for each variable are in the appendix.

2. Calculating the Index of each variable, the formula for calculating the Index on each variable is as follows:

Formula l Financial Transparency Index (I-TK0l)

$$
(01)=D_{1}^{1} x V_{1}^{1} x S+D_{1}^{1} x V_{1}^{2} x S \text { or }(01)=D_{1}^{1}\left(V_{1}^{1} x S+V_{1}^{2} x S\right)
$$


Where:

(01) is the dimension of financial transparency

$D_{1}^{1} l$ is the 0.39 weight needed to dimension 01

$V_{1}^{1}$ is the weight of 0.55 required to the 1 -dimensional variable 01

$V_{1}^{2}$ is the 0.45 weight required to the 2 -dimensional variable 01

$S$ is a Likert scale value between 1-5

Another model is I-TRANZOI $=\frac{I T K 1+I T K 2}{5}$

Where,

$$
\begin{aligned}
& I T K 1=D_{1}^{1} x V_{1}^{1} x S \ldots \\
& \text { ITK2 }=D_{1}^{1} x V_{1}^{2} x S .
\end{aligned}
$$

Formula 2 Management Transparency Index (I-TM02)

$(02)=D_{2}^{2} x V_{2}^{3} x S+D_{2}^{2} x V_{2}^{4} x S+D_{2}^{2} x V_{2}^{5} x S+D_{2}^{2} x V_{2}^{6} x S$ or,

$(02)=D_{2}^{2}\left(V_{2}^{3} x S+V_{2}^{4} x S+V_{2}^{5} x S+V_{2}^{6} x S\right)$

Where:

(02) is the dimension of management transparency

$D_{2}^{2}$ is the 0.29 weight required to dimension 02

$V_{2}^{3}$ is the 0.32 weight required to the 3 -dimensional variable 02

$V_{2}^{4}$ is the weight of 0.23 required to the 4 -dimensional variable 02

$V_{2}^{5}$ is the weight of 0.21 required to the 5-dimensional variable 02

$V_{2}^{6}$ is the 0.24 weight required to the 6 -dimensional variable 02

$S$ is a Likert scale value between 1-5 
Lebih lanjut I-TM02 $=\frac{I T M 3+I T M 4+I T M 5+I T M 6}{5}$

Dimana,

$$
\begin{aligned}
& \text { ITM3 }=D_{2}^{2} x V_{2}^{3} \times S \\
& \text { ITM4 }=D_{2}^{2} \times V_{2}^{4} \times S \\
& \text { ITM5 }=D_{2}^{2} x V_{2}^{5} \times S \\
& \text { ITM6 }=D_{2}^{2} x V_{2}^{6} \times S
\end{aligned}
$$

Furthermore I-TM02 $=\frac{I T M 3+I T M 4+I T M 5+I T M 6}{5}$

Where,

$$
\begin{aligned}
& \text { ITM3 }=D_{2}^{2} x V_{2}^{3} x S . \\
& \text { ITM4 }=D_{2}^{2} x V_{2}^{4} x S . \\
& \text { ITM5 }=D_{2}^{2} x V_{2}^{5} x S . \\
& \text { ITM6 }=D_{2}^{2} x V_{2}^{6} x S .
\end{aligned}
$$

Rumus 3 Indeks Transparansi Program (I-TP03)

(03) $=D_{3}^{3} x V_{3}^{7} x S+D_{3}^{3} x V_{3}^{8} x S+D_{3}^{3} x V_{3}^{9} x S$ or

$(03)=D_{3}^{3}\left(V_{3}^{7} x S+V_{3}^{8} x S+V_{3}^{9} x S\right)$

Where,

(03) is the dimension of program transparency

$D_{3}^{3}$ is the weight of 0.32 required to dimension 03

$V_{3}^{7}$ is the weight of 0.52 required to the 7 -dimensional variable 03

$V_{3}^{8}$ is the 0.23 weight required to the 038 dimension variable

$V_{3}^{9}$ is the 0.25 weight required to the 9 -dimensional variable 03

S is a Likert scale value between 1-5 


$$
\operatorname{ITP} 9=D_{3}^{3} x V_{3}^{9} x S
$$

$$
\operatorname{Itranz}=(\mathrm{I}-\mathrm{TK} 01)+(\mathrm{I}-\mathrm{TM} 02)+(\mathrm{I}-\mathrm{TP} 03)
$$

Furthermore I-TP03 $\frac{I T P 7+I T P 8+I T P 9}{5}$.

where,

$$
\begin{aligned}
& \text { ITP7 }=D_{3}^{3} x V_{3}^{7} x S . \\
& \text { ITP8 }=D_{3}^{3} x V_{3}^{8} x S . \\
& \text { ITP9 }=D_{3}^{3} x V_{3}^{9} x S .
\end{aligned}
$$

$$
\mathrm{I}-\mathrm{TRANZ}=(\mathrm{I}-\mathrm{TK} 01)+(\mathrm{I}-\mathrm{TM} 02)+(\mathrm{I}-\mathrm{TP} 03)
$$

\subsection{Rating Range and Rating Category}

The assessment categories used in determining the OPZ transparency index can be seen in the following table:

Table 3 Rating Categories on the OPZ Transparency Index Indeks

\begin{tabular}{rll}
\hline No. & Skor & Criteria \\
\hline a. & $0.00-0.25$ & Not transparent \\
\hline b. & $0.26-0.50$ & Less Transparent \\
\hline a. & $0.51-0.75$ & Fairly Transparent \\
\hline b. & $0.76-1.00$ & Transparent \\
\hline
\end{tabular}

Source: Puskas Baznas (2019b)

The range of values used in the Index is between 0.00-1.00. The closer to 1.00, the better the transparency of zakat institutions. Furthermore, four categories of assessment are used to determine the level of transparency in the Index.

If the range of values obtained by zakat institutions is in the field of 0.00-0.25, it is included in the non-transparent category. Meanwhile, it is included in the less transparent category between the numbers 0.26-0.50. Then, if the index measurement results are in the range of 0.51-0.75, it is categorized as quite transparent. Furthermore, the index value, which is in the field of $0.76-1.00$, means that the practice of transparency in zakat institutions is already evident. 
Fathoni \& Fakhrudin/Li Falah-Jurnal Studi Ekonomi dan Bisnis Islam, Volume 6 (No.1 2021)2262

\section{Result and Discussion}

In measuring the Amil Zakat Institution (LAZ) transparency index in Banten Province, the authors involved 5 LAZs, namely Harapan Dhuafa, PPPA Darul Quran, Baitul Ummah, Orphans Dhuafa, and Dompet Dhuafa. Each score was obtained from the five LAZs, which would later be included in calculating the transparency index. The process of calculating the transparency index of each LAZ can be seen in the following table:

Table 4 Calculation of Transparency Index of Amil Zakat Institutions

\begin{tabular}{|c|c|c|c|c|c|c|c|c|c|c|c|c|c|c|c|c|c|c|}
\hline KODE VARIABEL & V1.1A & V1.1B & V1.2A & V1.2B & $\mathrm{V} 1.2 \mathrm{C}$ & $\mathrm{V} 2.1 \mathrm{~A}$ & $\mathrm{~V} 2.1 \mathrm{~B}$ & $\mathrm{~V} 2.1 \mathrm{C}$ & V2.2 & $\mathrm{V} 2.3$ & V2.4 & V3.1A & V3.1B & V3.2A & V3.2B & V3.2C & V3.3A & V3.3B \\
\hline ВОВОT DIMENSI (D) & 0,39 & 0,39 & 0,39 & 0,39 & 0,39 & 0,29 & 0,29 & 0,29 & 0,29 & 0,29 & 0,29 & 0,32 & 0,32 & 0,32 & 0,32 & 0,32 & 0,32 & 0,32 \\
\hline BOBOT VARIABEL (V) & 0,55 & 0,55 & 0,45 & 0,45 & 0,45 & 0,32 & 0,32 & 0,32 & 0,23 & 0,21 & 0,24 & 0,52 & 0,52 & 0,23 & 0,23 & 0,23 & 0,25 & 0,25 \\
\hline SKOR (S) HARFA & 1 & 1 & 1 & 5 & 4 & 2 & 5 & 5 & 5 & 5 & 5 & 5 & 5 & 5 & 5 & 5 & 5 & 5 \\
\hline SKOR (S) PPPA DQ & 2 & 5 & 1 & 5 & 5 & 2 & 3 & 3 & 5 & 5 & 5 & 5 & 4 & 5 & 5 & 5 & 5 & 5 \\
\hline SKOR (S) BAITUL UMMAH & 1 & 1 & 1 & 4 & 1 & 2 & 5 & 3 & 2 & 1 & 3 & 3 & 2 & 5 & 5 & 5 & 3 & 3 \\
\hline SKOR (S) YATIM DHUAFA & 5 & 2 & 1 & 5 & 5 & 3 & 5 & 4 & 4 & 4 & 3 & 4 & 4 & 5 & 5 & 3 & 3 & 5 \\
\hline SKOR (S) DOMPET DHUAFA & 5 & 2 & 1 & 4 & 5 & 3 & 5 & 3 & 4 & 4 & 3 & 4 & 4 & 5 & 3 & 3 & 3 & 5 \\
\hline$D \times V \times S$ HARFA & 0,2145 & 0,215 & 0,1755 & 0,878 & 0,702 & 0,186 & 0,464 & 0,464 & 0,334 & 0,305 & 0,348 & 0,832 & 0,832 & 0,368 & 0,368 & \begin{tabular}{|l|l|}
3 & 0,368 \\
\end{tabular} & 0,4 & 0,4 \\
\hline$D \times V \times S$ PPPA DQ & 0,429 & 1,073 & 0,176 & 0,878 & 0,878 & 0,186 & 0,278 & 0,278 & 0,334 & 0,305 & 0,348 & 0,832 & 0,666 & 0,368 & 0,368 & 0,368 & 0,4 & 0,4 \\
\hline$D \times V \times S$ BAITUL UMMAH & 0,2145 & 0,215 & 0,176 & 0,702 & 0,176 & 0,186 & 0,464 & 0,278 & 0,133 & 0,061 & 0,209 & 0,499 & 0,333 & 0,368 & 0,368 & $\begin{array}{l}3 \\
\end{array}$ & 0,24 & 0,24 \\
\hline DXV XS YATIM DHUAFA & 1,073 & 0,429 & 0,176 & 0,878 & 0,878 & 0,278 & 0,464 & 0,371 & 0,267 & 0,244 & 0,209 & 0,666 & 0,666 & 0,368 & 0,368 & 0,221 & 0,24 & 0,4 \\
\hline$D \times V \times S$ DOMPET DHUAFA & 1,073 & 0,429 & 0,176 & 0,702 & 0,878 & 0,278 & 0,464 & 0,278 & 0,267 & 0,244 & 0,209 & 0,666 & 0,666 & 0,368 & 0,221 & | 0,221 & 0,24 & 0,4 \\
\hline
\end{tabular}

Calculation of the Amil Zakat Transparency Index is based on the weighting of each dimension and variable. The amount of weighting is based on the strength of each size and variable in showing the transparency of the Amil Zakat Institution. The final weight of each transparency indicator is based on the score obtained at each Amil Zakat Institution. The following is the transparency index of each Amil Zakat Institution:

\section{Zakat Transparency Index of Amil Zakat Institutions Hope Dhuafa Banten}

The calculation of the total Transparency Index of the Amil Zakat Institution of Harapan Dhuafa Banten is based on calculating the transparency index of each dimension. Financial transparency, management transparency, and program transparency are three dimensions included in the calculation of the transparency index of the Harapan Dhuafa Banten Amil Zakat Institute. The following is the result of the analysis of the Transparency Index of the Amil Zakat Institution of Hope Dhuafa Banten: 
Fathoni \&E Fakhrudin/Li Falah-Jurnal Studi Ekonomi dan Bisnis Islam, Volume 6 (No.1 2021)2262

Table 5 Transparency Zakat Index of Amil Zakat Institutions Hope Dhuafa Banten

\begin{tabular}{ll}
\hline DIMENSIONS & SCORE \\
\hline Financial Transparency Index & 0,159 \\
\hline Management Transparency Index & 0,271 \\
\hline Transparency Index Program & 0,320 \\
\hline Total Amil Zakat Institution Transparency Index Score & 0,751 \\
\hline
\end{tabular}

Source: Data processed

Based on Table 5, it can be seen that each of the transparency scores of each dimension. For example, financial transparency gets a score of 0.159. This finding is because disclosure of information on financial statements is an indicator in calculating financial transparency. Meanwhile, management transparency which is calculated using indicators of openness in managing organizations and public services gets a score of 0.271 . Meanwhile, collecting and distributing zakat are the leading indicators of the program transparency score. The transparency of the amil zakat institution program received a score of 0.320 . From these three dimensions, the total transparency index score of the amil zakat institution can be calculated, which is 0.751 . The range of values and categorization of the assessment on the $\mathrm{OPZ}$ transparency index is included in the criteria for being quite transparent.

2. The Zakat Transparency Index of the Amil Zakat Institution of the Daarul Qur'an Nusantara Foundation (PPPA)

The calculation of the zakat transparency index of the amil zakat institution of the Daarul Quran Nusantara Foundation (PPPA) is based on three dimensions, namely financial, management, and program transparency. The results of the calculations of these three dimensions and the total transparency index of zakat. Zakat institutions of the Daarul Quran Nusantara Foundation (PPPA) can be seen in the following table:

Table 6 Zakat Transparency Index for Amil Zakat Institutions Daarul Qur'an Nusantara Foundation (PPPA)

\begin{tabular}{ll}
\hline DIMENSIONS & SKOR \\
\hline Financial Transparency Index & 0,279 \\
\hline Management Transparency Index & 0,246 \\
\hline Program Transparency Index & 0,303 \\
\hline Total Amil Zakat Institution Transparency Index Score & 0,829
\end{tabular}

Source: Data processed 
Based on Table 6, it can be seen that each of the financial, management, and program transparency index scores, each of which gets a score of 0.279, 0.246, and 0.303. Meanwhile, the total transparency index of the amil zakat institution of the Daarul Qur'an Nusantara (PPPA) foundation is 0.829 . The range of values and categorization of the assessment on the OPZ transparency index is included in the transparent criteria.

3. The Zakat Transparency Index of the Baitul Ummah Foundation of the Amil Zakat Institution, Banten

The results of the calculations of the three dimensions (finance, management, and programs) as well as the total transparency index of zakat, zakat amil, and zakat institutions Baitul Ummah Banten foundation can be seen in the following table:

Table 7 Transparency of Zakat of the Amil Zakat Institution of the Baitul Ummah Foundation of Banten

\begin{tabular}{ll}
\hline DIMENSIONS & SKOR \\
\hline Financial Transparency Index & 0,113 \\
\hline Management Transparency Index & 0,142 \\
\hline Program Transparency Index & 0,204 \\
\hline Total Amil Zakat Institution Transparency Index Score & 0,460
\end{tabular}

Source: Data processed

Based on Table 7, it can be seen that the respective financial, management and program transparency index scores get a score of 0.113, 0.142, and 0.204, respectively. Meanwhile, the total transparency index of the amil zakat institution of the Baitul Ummah Banten foundation is 0.460 . The range of values and the assessment categorization on the OPZ transparency index is included in the less transparent criteria.

\section{The Zakat Transparency Index of the Amil Zakat Institution of the Griya Yatim Dhuafa Yayasan Foundation}

The results of the calculation of the dimensions of financial transparency, management transparency, and program transparency, as well as the total zakat transparency index of the amil zakat institution of the Griya Yatim Dhuafa foundation, can be seen in the following table: 
Fathoni \&E Fakhrudin/Li Falah-Jurnal Studi Ekonomi dan Bisnis Islam, Volume 6 (No.1 2021)2262

Table 8 Transparency of Zakat of the Amil Zakat Institution of the Griya Yatim Dhuafa Foundation

\begin{tabular}{ll}
\hline DIMENSIONS & SKOR \\
\hline Financial Transparency Index & 0,279 \\
\hline Management Transparency Index & 0,218 \\
\hline Program Transparency Index & 0,261 \\
\hline Total Amil Zakat Institution Transparency Index Score & 0,758 \\
\hline
\end{tabular}

Source: Data processed

Based on Table 8, it can be seen that each of the financial, management, and program transparency index scores, each of which gets a score of 0.279, 0.218, and 0.261. Meanwhile, the total transparency index of the amil zakat institution of the Griya Yatim Dhuafa foundation is 0.758 . The range of values and categorization of the assessment on the OPZ transparency index is included in the transparent criteria.

\section{Transparency Index of Dompet Dhuafa Amil Zakat Institutions}

The calculation of the zakat transparency index of the amil zakat institution of the Dompet Dhuafa foundation is based on three dimensions: financial, management, and program transparency. The results of the calculation of these three dimensions and the total transparency index of zakat amil zakat institutions in Dompet Dhuafa can be seen in the following table:

Table 9 Transparency of Amil Zakat Institutions in Dompet Dhuafa

\begin{tabular}{ll}
\hline DIMENSIONS & SKOR \\
\hline Financial Transparency Index & 0,267 \\
\hline Management Transparency Index & 0,212 \\
\hline Program Transparency Index & 0,251 \\
\hline Total Amil Zakat Institution Transparency Index Score & 0,730
\end{tabular}

Source: Data processed

Based on Table 9, it can be seen that each of the transparency scores of each dimension. For example, financial transparency gets a score of 0.267. Meanwhile, management transparency gets a score of 0.212. Meanwhile, the transparency score of the zakat collection and distribution program of the amil zakat institutions got a score of 0.25l. From these three dimensions, the total transparency index score of the amil zakat institution can be calculated, which is 0.730 . The range of values and categorization of the assessment on the OPZ transparency index is included in the criteria for being quite transparent. 
The Amil Zakat Institutions Transparency Index contains three main dimensions, nine variables, and 18 indicators of measurement components in the Index. The three indicators that make up the Index components are the dimensions of financial transparency, management transparency, and program transparency dimensions. By calculating the transparency index of the five Amil Zakat Institutions in Banten Province, the average index value is 0.706 . This value is in the range of $0.51-0.75$, so the transparency practice of the Amil Zakat Institution in Banten Province is categorized as quite transparent.

The lack of maximum application of transparency from several financial transparency indicators is one of the causes of the openness of the Amil Zakat Institution in Banten Province in the fairly transparent category. First, several Amil Zakat institutions do not publish their financial reports through websites, mass media, or other electronic media. In the digitalization era, the disclosure of information through websites and other social media indicates how transparent the Amil Zakat Institution is. Second, the financial reporting of the Amil Zakat Institution is not integrated with the Baznas Management Information System (SIMBA). Such conditions are not in line with the national zakat strategic plan for 2016-2020, where the Amil Zakat Institution Information System is well integrated with SIMBA. The presence of SIMBA is designed to make reports, storing data and information owned by BAZNAS as an institution that is mandated to be the coordinator of zakat management nationally. Web-based, SiMBA is a centralized application to be used by Provincial BAZNAS, Regency/City BAZNAS, and LAZ without having to go through a complicated installation process. 


\section{Conclusion}

As an institution that manages public funds, transparency is essential for the Amil Zakat Institution. The more open the Amil Zakat Institute to the public, the more trustworthiness of muzaki to pay zakat through the Amil Zakat Institution in their respective regions. Banten Province has a considerable zakat potential, but there is a gap between the potential for zakat and the reality of collecting zakat funds. This condition causes the empowerment of zakat as an instrument in poverty alleviation is not maximal, especially in Banten Province. So it is necessary to measure the transparency of the Amil Zakat Institution as an evaluation material in realizing public trust.

The Amil Zakat Institution Transparency Index is an indicator that can measure the level of transparency as a whole by looking at three important aspects, namely transparency in financial management, governance and management, and transparency in aspects of collection and distribution programs. These three dimensions are reduced to 9 variables and 18 indicators that are very relevant in assessing the practice of openness in the Amil Zakat Institution. Based on the research results on measuring the transparency index of the five Amil Zakat Institutions in Banten Province, 2 Amil Zakat Institutions fall into the transparent category, 2 Amil Zakat Institutions in the relatively fine category, and 1 Amil Zakat Institution in the less transparent category. From the average transparency index calculation, the Amil Zakat Institution in Banten Province is included in the reasonably good category with an index of 0.706 . 
Fathoni \& Fakhrudin/Li Falah-Jurnal Studi Ekonomi dan Bisnis Islam, Volume 6 (No.1 2021)2262

\section{References}

Adnan, M. A. (2017). The need to establish professional amil zakat to enhance future zakat development. International Journal of Zakat, 2(1), 71-79.

Amalia, E., Rodoni, A., \& Tahliani, H. (2018). Good Governance in Strengthening the Performance of Zakat Institutions in Indonesia. KnE Social Sciences, 223-24l.

Antonio, Muhammad Shafi'i (2002). Bank Syariah: dari teori ke praktik. Jakarta: Gema Insani.

Ascarya \& Yumanita, D. (2019). Analisis Rendahnya Pengumpulan Zakat Di Indonesia Dan Alternatif Solusinya (No. WP/9/2018).

Asfarina, M., Ascarya, A., \& Beik, I. S. (2019). Classical and Contemporary Fiqh Approaches to ReEstimating The Zakat Potential in Indonesia. Journal of Islamic Monetary Economics and Finance, 5(2), 387-418.

Badan Pusat Statistik. (2019). Diakses pada tanggal 2 April 2020 dari https:/www.bps.go.id/subject/23/kemiskinan-dan ketimpangan.

Barth, M. E., \& Schipper, K. (2008). Financial reporting transparency. Journal of Accounting, Auditing \& Finance, 23(2), 173-190.

Barth, M. E., Konchitchki, Y., \& Landsman, W. R. (2013). Cost of capital and earnings transparency. Journal of Accounting and Economics, 55(2-3), 206-224.

Behn, B. K., DeVries, D. D., \& Lin, J. (2010). The determinants of transparency in nonprofit organizations: An exploratory study. Advances in Accounting, 26(1), 6-12.

Bushman, R. M., Piotroski, J. D., \& Smith, A. J. (2004). What determines corporate transparency?. Journal of accounting research, 42(2), 207-252.

Dubbink, W. (2007). The transparency gained, morality lost: A critique of the administrative conceptualization of CSR, illustrated by Dutch policy. BUSINESS AND SOCIETY REVIEWBOSTON AND NEW YORK-, 112(2), 287.

Firdaus, M., Beik, I. S., Irawan, T., \& Juanda, B. (2012). Economic estimation and determinations of Zakat potential in Indonesia. Jeddah: Islamic Research and Training Institute.

Gambling, T. E., \& Karim, R. A. A. (1986). Islam and 'social accounting'. Journal of Business Finance and Accounting, 13(1), 39-50

Haniffa, R. (2002). Social responsibility disclosure: An Islamic perspective. Indonesian Management and Accounting Journal. 1(2)

Huda, N., \& Sawarjuwono, T. (2013). Akuntabilitas Pengelolaan Zakat melalui Pendekatan Modifikasi Action Research. Jurnal Akuntansi Multiparadigma, 4(3), 376-388.

Indonesia Zakat Outlook. (2018). Diakses pada tanggal 2 April 2020 dari https://www.puskasbaznas.com/publications/outlook/indonesia-zakat-outlook 
Fathoni \& Fakhrudin/Li Falah-Jurnal Studi Ekonomi dan Bisnis Islam, Volume 6 (No.1 2021)2262

Indikator Pemetaan Potensi Zakat. (2019). Diakses pada tanggal 3 April 2020 dari https://www.puskasbaznas.com/publications/outlook/indonesia-zakat-outlook

Lewis, M. K. (2006). Accountability and Islam. Fourth International Conference on Accounting and Finance in Transitions. Adelaide, Australia

Nasri, R., Aeni, N., \& Haque, M. G. (2019). DETERMINATION OF PROFESSIONALISM, TRANSPARENCY, AND ITS IMPLICATIONS FOR THE FINANCIAL PERFORMANCE OF ZAKATINSTITUTIONS. Journal of Islamic Monetary Economics and Finance, 5(4), 785 806.

Nurfadhilah, I. R., \& Sasongko, C. (2019, July). Web-Based Accountability in an Islamic Non-Profit Organization: A Case Study of Badan Amil Zakat National in Indonesia. In Asia Pacific Business and Economics Conference (APBEC 2018). Atlantis Press.

Puskas Baznas. (2019a). Dampak Zakat Terhadap Kesejahteraan Mustahik di Pulau Jawa. Diakses pada tanggal 2 April 2020 dari https://www.puskasbaznas.com/publications/ officialnews

Puskas Baznas. (2019b). Indeks Transparansi Organisasi Pengelola Zakat (OPZ). Diakses pada tanggal 5 April 2020 dari https://www.puskasbaznas.com/ publications/ indonesiazakat-index/indeks-transparansi-opz

Saad, R. A. J., Abdul Aziz, N. M., \& Sawandi, N. (2014). Islamic accountability framework in the zakat funds management. Procedia-Social and Behavioral Sciences, 164, 508-515.

Statistik Baznas. (2019). Laporan Keuangan Tahun 2018. Diakses pada tanggal 2 April 2020 dari https://pid.baznas.go.id/tahun-2018/

Williams, C. C. (2005). Trust diffusion: The effect of interpersonal trust on structure, function, and organizational transparency. Business \& Society, 44(3), 357-368.

Williams, A. (2015). A global index of information transparency and accountability. Journal of Comparative Economics, 43(3), 804-824. 